\title{
Henry Fielding's Joseph Andrews: A Classic Journey into the Souls of Mankind
}

Peter Aringo-Bizimaana

Uganda Christian University, Mukono - Uganda

\begin{abstract}
This essay first gives some background to the making of Joseph Andrews: the seeds that fruited to make Fielding be labeled, by some critics, the 'father of the English novel'. The essay goes on to discuss the heroes of this novel and their thematic significance. We then dwell on weaknesses found in the novel: those related to the heroes and other characters owing to weak characterization, and then the weaknesses that arise from the angle of narration. The essay concludes with a brief assessment of why Fielding is still considered a literary giant today.
\end{abstract}

Keywords: Henry Fielding, comic epic, pilgrimage/journey, Josef Andrews, picaresque

\section{1- Introduction}

\subsection{Fielding's Scholarly Journey}

Baker (1957), Shaver (1941), Watt (1960), and Radloff (1957) give us quite an elaborate academic and professional profile Fielding went through before embarking on novel writing: a graduate of Eton Public school and a university scholar of the classics, Fielding was versed in the study and translation of the ancient Greek romances. He spoke classical languages: Latin and Greek and even added French. He was a voracious connoisseur of classic drama and philosophy, the Bible and other books of notable scholars and moralists of the time. But, Radolf (1957) notes that Fielding was especially indebted to Aristotle, Horace and Longinus (Radolf, 1957, p. 1) from whom, in Watt's words (1960), Fielding sought to extract classical standards of criticism to correct what he thought "the growing anarchy of literary taste (which) called for drastic measures" (Watt, 1960, p. 248). He was not satisfied with the experimentation and random effort in new scholarship (Baker, p. 1957). Little wonder, therefore, that Joseph Andrews contains so many allusions to and even quotations from texts of great learning. We also note, in the novel, why Pastor Adams has made Aeschylus his darling companion. To Fielding's scholarship was added a study of Law; then there was a plethora of reading materials (Taylor, 1934): the periodicals of the time - the Tetlar, Spectator, Guardian, Hambler, Adventurer, World, Connoisseur, Idler, Mirror, Lounger, Observer, Looker-on...all entertaining and some outright satirical attacks on corrupt practices of the day. All these provided an added strong reading 
background of fiction that steered him into prolific writing of plays (twenty-five) and then articles for various magazines and newspapers of the time. He earned the name journalist because he even founded "The Champion", a very controversial newspaper which turned out to be a platform for political battles against the social-moral-political corruption of the time (Shaver, 1941, pp. 29-34). He used it also for serializing his books. But, according to Bartkuvienè (2017),

(The real) source of Fielding's comedy is affectation (artificiality and pre-tence), which, according to Fielding, arises out of vanity or hypocrisy (as articulated in the Preface of the novel) as 'The only source of the true Ridiculous (which) is affectation of the day (and) proceeds from one of these two causes: vanity or hypocrisy: for as vanity puts us on affecting false characters, in order to purchase applause; so hypocrisy sets us on an endeavor to avoid censure, by concealing vices under an appearance of their opposite virtues... .' (Bartkuvienè, 2017, p. 27)

Shaver (1941) supports this trend because he attests Fielding had witnessed too much corruption and thought to write something that would teach his society to change.

\subsection{The Birth and Form of the Novel}

In the novel's introduction, Brissenden (1979) tells us that Fielding set out to write on a very important theme: philosophizing about how morals and religion could be practically translated into active morality instead of stressing God too little and Man too much. The novel, therefore, was to become an urgent call to society to retrace the dying virtues society was losing. It was also meant to carry his views on irritatingly mediocre writings on morality, Richardson's Pamela, to him, being one of these. A number of scholars have pointed out how, on responding to this kind of writing, Fielding, so to say, stumbled on a new mode of writing that ended up getting him labeled the 'father' of the English novel (Battestin, 1959; Maurer, 2014; Backscheider, 2005; Sneddon, 1998; Scott, 2008). This stemmed from the partial diversion from total picaresque tradition to the adoption of complex and multiple characters, the increase in setting episodes and expansion of themes that all went into making Joseph Andrews a new, unique eighteenth-century novel that many latter writers learnt narrative writing from. In other words, as Sneddon (1998) observes, the Preface was de-privileged of its intended form. He especially notes one of the key causes as the dropping of the initial narrator in the rest of the novel, so that the Preface cannot be said to describe well the nature of Joseph Andrews. Indeed, the single narrator of the Preface eventually "reassesses and rejects the non-binding statements he made in the Preface". An initial attempt to follow the Preface is actually made by the introduction of Fanny and Joseph as key figures to start on a parody of Pamela. Pamela, being the heroine of Richardson's Pamela, this extraordinary female of so-called incorruptible virtue, is said to have stirred Fielding's reaction to parody her using a male character, Joseph Andrews, who, in Joseph Andrews, turns out to be a brother to another Pamela who is not given sufficient characterization to bring out the ascetic chastity of Fanny, Joseph's target for marriage. To Fielding, therefore, using a male hero to show exemplary chastity becomes a more realistic way of teaching society what it entails protecting one's chastity by going through very trying temptations we are going to review in this essay. To Fielding, therefore, Richardson's Pamela was a fake because of, in Maurer's words (2014), 
Pamela's commoditization of female chastity and the novel's celebration of female duplicity and male naivety (so that) Fielding's creation of the chaste and virtuous Joseph attacks Richardson's novel in a different way: criticizing the "maiden in distress" convention by exposing a man, rather than a woman, to sexual dangers. By transposing the sexes and making Joseph adhere with such tenacity to a virtue not traditionally associated with men, Fielding highlights the ludicrous nature of Pamela's own adherence to virginity as the sole source of her own "illustrious" example. (Maurer, 2014, p. 105)

However, as the essay will show, the narration went on incorporating more characters and other materials than he had envisaged and ended up losing his initial major target: parodying Pamela.

\section{2- Discussion}

\subsection{Joseph Andrews as Partially Picaresque}

Brissenden's Introduction posits Fielding wanted to write a unique novel "in Imitation of the Manner of Cervantes, Author of Don Quixote, because Don Quixote certainly undergoes transformation" as opposed to the static Pamela of Richardson's Pamela (Fielding, 1979, p. 08) and her distorted sense of morality. However, Joseph Andrews ended up incorporating few of the traditional picaresque elements that he twisted into a comic prose poem properly called an adventure journey or a pilgrimage (Watt, 1960; Battenstin, 1959; Kettle, 1960; Allen, 1963; Mace, 2018). Of the traditional six epic elements (in Aristotelian tragedy: meter, fable, action, characters, sentiments, and diction), Watt (1960, p. 248) summarizes the views of such critics when he says Fielding used all except meter because, in a comic epic, they are unavoidable; he says, "It is surely impossible to conceive of any narrative whatever which does not in some way contain 'fable, action, characters, sentiments, and diction'. The possession of these five elements certainly does nothing to elucidate the distinction which Fielding goes on to make between the prose epic and French romances". So, the novel took another turn.

\subsection{A Symbolic Journey Beyond the Mere Traditional Picaresque Journey}

The only difference from the traditional picaresque lies first of all in the depiction of his heroes as non-rogues as would be in the Spanish works. But Joseph Andrews still bears some elements of roguery: the criminals and rogues are encountered on this journey by the heroes but are not cast prominent characters; the humorous events/episodes are many and very engaging; the traditional epic battles are represented by the fights and escapades the heroes of Joseph Andrews go through, and, of course, the moral is there constantly hammered out to the reader: have active Charity, avoid affectation and its evils (vanity and hypocrisy). So, Fielding ended up with a scathing attack on his society, turning the novel into some "moral fable" because it is the moral intention that shapes the novel (Battestin, 1959, pp. 88-89). It all ties up with Fielding's critical mind: he had read Don Quiote (Cervantes) and digested the common vices gripping European society. He had read Robinson Crusoe, Guliver's Travels and other early 'prose fiction', as Downie (1997) and Baker (1957) prefer to call these early works. He had seen the growing individualism, materialism and hypocrisy of his England, especially the vices of London as a symbol of sin, and so he chose to combine the well-known pilgrimage motif with Bible 
stories his society knew well. This is why the journey motif style becomes a symbolic search into the souls of the people his heroes encounter, and who end up also as symbols of people in Fielding's England at the time. The journey symbol takes on an attractive diversion into more religious elements: the Biblical allusions to important Genesis figures - Abrahams the Biblical father of nations; and then Joseph son of Jacob sold into exile to King Potipha by his step-brothers. This is how the two Bible figures inspired Fielding to develop Joseph and Adams. Joseph became a perfect rebuttal to Pamela. The parallels with the Biblical Joseph are glaring: the Biblical Joseph is exiled from his parents and people, is sexually harassed and tormented by the queen, causing the very hateful rift between them because in the Genesis Joseph keeps a tenacious restraint against soiling his chastity. It was an attractive lure and Fielding's society would understand the message very well: Joseph's (and Adam's) symbolic journey from the well-known vices of London to the relative sanity and humility of the countryside people.

\subsection{Fielding's Heroes}

\subsubsection{Joseph Andrews}

Though said to be the first hero of the novel, Joseph Andrews would not be what he is without a companion who calls him 'child' and defends him and his girlfriend at every stage of their journey. This is why Pastor Adams forms a complementary hero of the novel (Battestin, 1959; Scott, 2008; Maurer, 2014; et al). It is Adams who actually ends up leading his people from Egypt to Canaan (Mauer, 2014). The two heroes, therefore, are meant to, respectively, carry the great themes of chastity and social charity as Fielding intended to articulate. Drawn as a poor footman with no material possessions and no parents, but as a very strong and handsome young man, Joseph is a sure target for bribes particularly from his rich mistress ready to offer anything for sexual gratification. Lady Booby, like her name suggests, becomes a very dangerous booby trap for the young man. When rejected, she turns into a tigress, mad libido personified. The situation is worsened by her forty-five-year-old maid, Slipslop whose name also is suggestive of riding roughshod on men she wants to trap and who will even use force where possible like on the last night of their stay at Lady Booby's Booby-Hall when she grapples with Beau Didapper and Pastor Adams. Even when Fanny comes into the story, the craving of the two women for Joseph is worsened by jealousy and murderous hatred for Fanny. Naturally in satire, the grotesque becomes a natural representation of the two wicked women because the ferocity with which they hunt for Joseph is life-threatening. They will not leave him alone even when he has been dismissed from his job, but instead, they shamelessly compete, each intent on winning him away from Fanny. The girlfriend becomes a very good antithesis to these women's uncontrollable craving for sexual favors. It is pathetic to hear them appealing to him as if their lives depended on his acceptance of being ravaged. With Lady Booby, it is not even adultery he rejects because her husband is dead; it is just that he carries a strong feeling of betraying the trust Sir Booby has had in him, just like the Joseph of Genesis dared not betray his kind master. So, in her desperation, Lady Booby whines, "Don't pretend to too much modesty... Would you not be my master?... To torment me and remind me of (my dead husband) ...". And then she burst into a fit of tears... (Fielding, 1979, pp. 48-50). And then, like a desperate refrain, Mrs. Slipslop attacks next, "I am convicted you must see the value I have for you... my eyes must have declared a passion I cannot conquer... Oh, Joseph!” (Fielding, 1979, p. 53). And Fielding gives them 
such predator names as 'tigress, voracious puke... preparing to leap on her prey....'. Especially for Mrs. Slipslop, with her pretentious knowledge of good English and good education, she sounds a savage indeed on a life-and-death hunt.

At the Dragon Inn where Joseph lies recuperating from battering by thieves who leave him penniless, another predator, Betty the chambermaid, cannot resist offering herself to Joseph. She is another good example of the satirical twist Fielding levels against selfish charity, just like the many would-be good Samaritans offering to help Adams and Joseph for profit. So, these exaggerated attacks on Joseph's chastity go a long way to underscore Fielding's lesson: the moral degeneracy is not only confined to the rich ladies who find easy life a pass-time, but also to the poor. The behavior of Leonora leaving Horatio for the richer Bellarmine, the litany of easy women and prostitutes Wilson talks of to Adams, and the women adding to this litany in the various coaches they are in travelling with Fielding's heroes, all these go a long way to emphasize Fielding's theme of sexual hypocrisy arising from affectation, vanity and prudery (Fielding, 1979, p. 199). Fielding uses Wilson to underscore this vice (Fielding, 1979, p. 207): "Vanity is the worst of passions and more apt to contaminate the mind than any other: for, as selfishness is much more general than we please to allow it, so it is natural to hate and envy those who stand between us and the Good we desire". One sees, therefore, how contrasting Fanny with these other women gives readers the conviction that Joseph is justified to preserve his chastity as Fielding's robust celebration of this theme. This is complemented by Fanny's equal robust determination to fight against any lustful temptations or even attempts to rape her. According to Battestin (1959), her simple, unsophisticated comportment and unpretentious commitment to Joseph and his equally adoring care for her bring up the sentimentalism in the novel, but it becomes part of the dramatization of "good nature" the author wants to promote, and which he harps on all the time (Mace, 2018, p. 16). This is to bring a reader's admiration for the two lovers who are sharply contrasted to Lady Booby, Mrs. Slipslop, and then the London whores Wilson details for us. In the words of Maurer (2014),

lust, as manifested in these (sexy) predator characters, can never be truly satisfied: its fluid endlessly exchangeable nature is continually compared to the more stable, chaste, and exclusive passion felt by Joseph and Fanny, a passion described by the narrator as meriting "the noble Name of Love". It is shown they have a strong sexual attraction for each other, but this is controlled with modesty to wait for conjugal union. Even when faced with the possibility that they might be siblings, they demonstrate their exemplary ability to sacrifice desire to love, declaring that they would choose "perpetual Celibacy" in order that they might live together all their Days. (Maurer, 2014, p. 105)

\subsubsection{Pastor Adams Versus Other Dramatized Mean Characters}

Like his Biblical namesake, Adams gives the Biblical allusion a deeper allegory: the benevolent father figure, the good example of unselfish neighborliness, charity and mutual love human beings should cultivate. It is reinforced by another Biblical allusion to The Good Samaritan story: the postilion who helps Joseph into the stage-coach, covers his nakedness and helps him to the Dragon Inn; those who rescue Fanny twice from being ravaged, etc. So, Adams, too, takes on a symbolic significance: what all 
people, especially the clergy, should be unlike the beastly and selfish hearts of pastors like Trulliber and then the magistrates and squires we encounter. Adams is also like a Moses of the Bible (Mauer, p. 2017): he is leading the children of God from an evil land to the Promised Land of love and charity. To appreciate the crucial thematic importance Adams stands for, we need, therefore, to examine one of his complete opposite: Pastor Trulliber.

Fielding intentionally gives Pastor Trulliber a character portrayal of a pig (Sumpter, 1978, p. 37): the unmistakable symbolism. He keeps pigs to which he is immensely 'devoted to serve' because they have replaced the devotion he should have for his parishioners; attention to religious issues is done only on Sunday, the rest of the weekdays are devoted to the pigs; he is as fat as they are, eats as rapaciously as they do and slobbers as they do; he is as greedy as they are and mean, selfish and completely indifferent to human suffering because, animal-like, he cares only for self; his pigs' dirty and stinky external is symbolized in his morally dirty, stinky heart. Therefore, placed on the same pedestal with animal existence, we have a moral monster far from the tenets Christianity demands of a Pastor since he is "a travesty of the authority of that position" (Sumpter, 1978, p. 37). His rude and violent treatment of his wife alone demonstrates animal nature, selfish to the extreme. No wonder his parishioners face him with trepidation because the pastoral authority has been replaced by a distorted authority much like the iron hold the judges, magistrates and squires have on the poor (Brennan, 2010, p. 57). So, Trulliber is part of their corruption. When Adams teaches him that Christianity is to be practiced as well as preached, the animal in the so-called pastor readies for attack, but Adams stretches out his ox-like-paw of a fist; Tulliber reads the menacing message and backs off. The same insensitivity to human suffering is shown by Pastor Barnabas: just like his magistrate and surgeon friends, his interest in the beaten and sick Joseph is in what he could profit from the patient: one of the captured thieves promises pecuniary court fines and a reward for his capture. Barnabas has an eye on the shares that accrue from such a hunt. So, like a hyena following a pride of hunting lions, he has always known such situations to promise rich kills to feed on. In the small talk he holds with Joseph (Fielding) (Fielding, 1979, p. 75), they talk at cross purposes, Joseph pushing sarcastic barbs to imply the so-called 'spiritual' nourishment he has brought to the sick as nothing but hypocrisy-display.

This intentional contrast, therefore, places Adams at the fore as chief carrier of the theme of charity. As we shall discuss later in $3(a)$, although many critics have also given Adams a good supply of negative descriptions, still Fielding's intention is for readers to admire this shining example of an unselfish, generous heart. He truly lives a Christian life as a cosmopolitan minister (Shaver, 1941, p. 129), and not a hypocritical follower of dogmatism. His idiosyncrasies are to be seen as depiction of a true self, responding to circumstances like many men would do especially when it is demanded he defend a just cause. This is why right from the beginning the narrator tells us that Adams is given the ability of

surprising us - usually because his response to things, particularly to new and testing situations, has an almost childish freshness and spontaneity (and he) is the unique embodiment of a vigorous, innocent and ... rational enjoyment of life: reading Aeschylus, drinking beer, smoking his pipe, arguing solidly about the beauties of Homer or the duties of a Christian - these varied 
activities provide him with a due measure of joy and satisfaction (making) the best of every situation (as completely appropriate) part of his whole character. (Fielding, 1979, pp. 16-17)

Walter Allen (1963) adds to this stating that Adams is eccentric at times and rather ridiculous,

yet the most splendid character in Joseph Andrews, indeed in all Fielding... and he is a creation of pure humor. Perhaps he owes something to Don Quiote, but he is every sense an original character, one of the archetypal characters in English fiction... Adams, with his absentmindedness, his small pedantries and vanities, his naive trust in human goodness, which is always betrayed, is the heart of the novel. (Allen, 1963, p. 56)

This agrees with that allusion to the Biblical father figure, taking the central role of what Maurer (2004) calls leading God's people from Egypt to Eden as part and parcel of the idealized Virtue of universal Christian love and charity Fielding is advancing. This is why the whole journey involves him in vigorous actions and arguments against all manner of adversaries of this virtue. Juxtaposed against the villains of the novel, he actually turns into a mobile test of their vices and a tool for Fielding's satire to succeed, and indeed Fielding is asking readers to also react to the ironic and humorously ridiculous reactions of the villains to this litmus test. We, therefore, note an exposition of many evils: the hypocrisy and materialism of the clergy; the affectation and vanity of lecherous and materialistic women; the exsoldier (symbol) swearing he has war-hardened courage, yet he cannot help in the rescuing of Fanny from almost being raped; the Tou-wouses openly preaching individualism against Adams' "meaningless" unselfish charity and brotherhood to the needy, etc. In all this, there is an apparent war of the Haves and privileged against the poor and defenseless. Throughout the novel, therefore, humble travelers become objects of our attention, sympathy and admiration. We think this is how Fielding has succeeded in making his epic break away from the old epics that lionized the royalists, the rich and powerful such as the aristocracy, the knights, squires and nobles. In Battestin's words (1959), Adams, therefore, becomes "the fullest personification of good nature" (p. 111) because he has the essential characteristics of this positive sentimental concept of charity so that his innocence and idealism become effective vehicles for exposing follies and vices of any society. This is what qualifies him to indeed take up the roles of pilgrim priest and knowledgeable patriarch well versed in classics and keeping unchanged in the company of so many idolatrous beings through control of passions.

\subsubsection{Adams on Education}

Paula McDowell (2005) rightly argues that

Fielding challenges key assumptions of arguments for broader schooling. By means of his central characters in both Joseph Andrews and Shamela (1741), he systematically shows that there is no necessary causal relationship between literacy and (i) virtue (his virtuous country lass Fanny Goodwill, the future wife of his hero, can neither read nor write); (ii) moral improvement (the corrupt Shamela Andrews devours books sent to her by her bawd mother and tutor in immorality, Parson Arthur Williams); or (iii) socioeconomic elevation (Parson Abraham Adams, the most 
"literate" character in Joseph Andrews, is patriarch of the most "ragged Family in the Parish," and subject to every kind of humiliation and contempt) p.17.

Indeed, as pointed out earlier, it is the insignificant and lowly characters that exhibit a sense of brotherhood, unlike the pompous rich scholars of Oxford and Public schools. From the start of the novel, Joseph tells us he is contented with his elementary education of Reading and Writing and whatever he has picked from few books he read and from eavesdropping discussions of the learned while employed at the Boobies. He tells Adams he has also read the Bible and other books of scholars on the Whole Duty of Man. Battestin (1959) rightly points out that whereas the pilgrims are used to satirize the follies within English countryside along the highway, Wilson is used to giving comprehensive ridicule of London vanities by taking us through his own education, career and the nearly fatal consequences of immorality and irreligion, which are twin results of a faulty education (Battestin, 1959, p. 129). Moreover, to Battestin, Joseph would have ended the same way without Adam's practical direction outside what Wilson calls the clubs of young men of abilities, truth seekers, free thinkers who prize man being sufficient to guide himself without the humbug of religion and Christian virtues (Fielding, 1979, p. 205). Backscheider, too, (2005) views Adam's (Fielding's) views on liberal education as destructive compared to the home education profits that Joseph is proud of instead of lamenting. He has, of course, also observed the nauseous affectation of a Mrs. Slipslop who wants to show off an 'advanced grasp of education' she never had; she is one of those representing those Fielding is mocking: the snobs who think their education or pseudo intelligence entitles them to lord it over others and to think themselves better people. Indeed, what is the use of formal education which creates a brute liar and mean Pastor Trulliber who keeps a slave wife and terrorized parishioners? (Fielding, 1979, pp. 163-67). Or a similar monster of greed and extortion, Pastor Barnabas (JA, pp. $84 \mathrm{ff}$ ) colluding with an equally corrupt Doctor and a Magistrate? Or the pretentious bookseller cheating honest writers of their due profits, an extortionist who almost entraps Adams but fails (JA, pp. $91 \mathrm{ff})$. It is interesting how, every after an encounter with each of these vile people, Adams (Fielding's apostrophizing) makes a summary comment about each. For instance, on this bookseller, he comments, "A virtuous and good Turk, or heathen, are more acceptable in the sight of their creator, than a vicious and wicked Christian tho' his faith was as perfectly orthodox as St Paul's himself..." (Fielding, 1979, p. 94).

What is even more convincing about false hopes in education is the characterization of Adams himself: he is a scholar of impressive education, yet, at fifty years of age, preaching regularly at four churches to make a living, poverty still trails him as symbolized in his attire: a dirty, tattered cassock that makes him almost a laughing stock wherever he goes. What actually makes him still respectable is his vocation and his sharp mind, out-reasoning fraudsters. And typical of him, he is not afraid to acknowledge he is among the poorest of the poor - struggling to feed and educate his six children and please a rather nagging wife who feels his charity (such as his hosting Fanny and Joseph) a huge budgetary burden on an already strained family budget. In fact, her occasional nagging, flashes of anger and an almost selfish, mean spirit are a result of poverty. Otherwise, she is a diligent parent and housewife. So, indeed, neither literacy nor higher learning seem to ensure socioeconomic advancement and will get you nowhere near the riches of the corrupt and those who have inherited fortunes. Adams, 
therefore, throughout the novel, lives to follow his contention: that morality has nothing to do with good education and riches. Instead "Emulation most effectively operates upon us, and inspires our imitation in an irresistible manner. A good man, therefore, is a standing lesson to all his acquaintance, and of far greater use in that narrow circle than a good book (especially given that) the best men are but little known, and consequently cannot extend the usefulness of their examples a great way..." (Fielding, 1979, p. 39).

And, to Adams, the "good books" certainly do not include poisonous publications but comprise those "communicating valuable patterns to the world... books finely written: to sow the seeds of virtue in youth, books comprehended by persons of moderate capacity" (Fielding, 1979, p. 39). It must also be understood, therefore, that Fielding is questioning the use of this education and expansive knowledge if it is going to produce hypocritical and corrupt officials and clergy as those discovered during the pilgrimage.

\subsection{Weaknesses}

In choosing satire, Fielding opened a door for the grotesque element, an extreme character painting that introduces ridiculous comedy in actions of even the heroes, thus opening the way for accusation of producing ironic and even flat heroes. We shall first examine these possible weaknesses in characters and then go on to demonstrate other stylistic elements that show some weak points of Joseph Andrews.

\subsubsection{Weaknesses in Characters}

\subsubsection{Pastor Abraham Adams}

First of all, this is the chief hero who is given very admirable qualities, some of which we have highlighted earlier. To these, he adds the commitment to his pastoral work and has proven an exemplary man of charity and will not countenance mistreatment to anyone he loves. Yet, he has an inexcusably glaring absent-mindedness that plunges him in problems and his co-pilgrims at critical times. For instance, forgetting his horse before setting off from London partly accounts for the near-death of Andrews and their having to encounter corrupt leaders represented by a doctor, a lawyer, Pastors Barnabas, Trulliper, a magistrate and a mean inn-keeper all of whom collude to get the sojourners mistreated and cheated, looking forward to extorting money from these victims. Moreover, there is also a case against his horse: money for horse food, which poor Joseph does not have, and an altercation begins with the Tou-wouses swearing to sue and even get interest for non-payment in time. Adams has earlier on set off to London, but after meeting a bookseller and pre-payment discussions begin, he remembers his books have been forgotten at home, Mrs. Adams having packed clothes, leaving no room for books. Then, after storming away from the inconsiderate Trulliber and has rejoined his friends, he remembers he has forgotten his hat and great coat; only the kind lady of the inn where they are sacrifices to go and retrieve the forgotten items. Adams even throws his beloved Aeschylus into the fire out of joy as he listens to Joseph and Fanny exchanging oaths of love and future marriage. Soon, back on the road, he pitiably roes this recklessness as he craves for companionship with his Aeschylus when loneliness 
sets in; but Joseph reminds him the book would be of no use even now because it is at night and there is no light to read by.

Secondly, his intelligence is made questionable owing to the contradictions he makes at times concerning the importance he attaches to learning philosophy and the classical literature, and to the reading of the Bible and other morally-edifying writers (Mace, 2010; Sneddon, 1998; Prior, 1997). So, his erudition bears no relation to critical self-examination or even common sense. For instance, Sneddon bases his criticism on Adams' naïve knowledge of people: Adams himself declares he had never known such monsters as Trulliber existed (Fielding, 1979, p. 169). Soon a gentleman at a squire's house tricks him that he is going to lend him money and even provide the group with horses to take them comfortably home. Adams is full of himself with happiness and praises for the good Samaritan. Soon excuses pour in: none of the promised things can be given. Adams is dumbfounded; he asks Joseph why the gentleman would gratuitously trick them. Joseph (Fielding), with a touch of sarcasm, very wisely answers - "It is not for me...to give Reasons for what Men do, to a Gentleman of your learning". Adams responds, "You say right... knowledge of Men is only to be learnt from Books, Plato and Seneca for that; and those are Authors, I am afraid, Child, you never read." To which Joseph (Fielding) again sarcastically retorts that they do not need learned authors at this critical time because "the generous Gentleman hath left us the whole Reckoning to pay." Devastated, Adams agrees he had never read of "such a monster" (Fielding, 1979, pp. 176-77). Another eavesdropping gentleman (Wilson) is the one who begins to educate Adams on some of the secrets of understanding human beings: Adams should not trust reading faces only or trusting only book-knowledge to understand people. "Ah! Master... if you had traveled as far as I have... you would not give any Credit to a Man's Countenance” (Fielding, 1979, pp. 180-82).

It would seem Fielding, in making Adams sound so unbelievably ignorant, is forgetting what he laid out about his hero in the Preface,

As to the character of Adams, as it is the most glaring in the whole, so I conceive it is not to be found in any book now extant. It is designed a character of perfect simplicity: and as the goodness of his heart will recommend him to the good-natured; so I hope it will excuse me to the gentlemen of his cloth; for whom, while they are worthy of their sacred order, no man can possibly have a greater respect. They will therefore excuse me, notwithstanding the low adventures in which he is engaged, that I have made him so many opportunities of displaying his worthy inclinations. (Fielding, 1979, p. 30)

This simplicity is verging on idiocy. Far from making it easier for critics to agree with his hero, this 'pre-ordination' and 'sanctification' of his hero prove what critics have variously branded campaigning for his hero to be acceptable to the reader: he uses him as a fixed tool of a campaign to reform the popular contempt of the clergy at the time (Sneddon, 1998, p. 38); for Mace (2018, p. 16), Fielding keeps appealing to our "good-natured" feelings and sympathies to accept idiosyncrasies of a puzzling character, which serves to intensify the irony. This kind of narrator-commentator's recommendation helps greatly to water down the credibility of his character (Kettle, 1960, p. 36); the fact that " Fielding's 
characters do not have a convincing inner life means that their possibilities of psychological development are very limited " and the fixity of Adams' robot-like response to circumstances is taking a static "view of human nature" (Watt, 1960, p. 273).

Sneddon (1998) rounds off this argument with what seems a fair summary of criticism against the characterization of Adams,

Fielding assures us that Adams is a portrait of Christian idealism and charity, "notwithstanding the low Adventures in which he is engaged" (Preface, p. 36). Yet he makes (him) undergo relentless, physical humiliations of the most slapstick kind. Among other "low Adventures", Adams is scalded with soup, covered with hogs' blood, set on fire with a candle, tumbled in the mud, and chased and pulled about by hounds. Fielding tells us how we are supposed to read Adams's character, but ... Fielding's contemporaries seldom followed his instructions: Many readers seemed incapable of seeing [Adams] as anything but the subject of ridicule. It was almost impossible (because) most readers fixed their thoughts on his oddities of dress and behavior, or 'the hounds trailing bacon in his pocket', and entirely overlooked "the noble simplicity of his mind", with the other innumerable beauties in his character. (Sneddon, 1998, p. 39)

Thirdly, Pastor Adams has an unpredictable temper that contradicts the high moral stance and belief in brotherhood and forgiveness that Fielding gives him: his constant clicking of fingers in pugilistic irritation is put into action to a worrying degree. He can swing his ox-paw fist at opponents to a devastating, almost fatal effect such as when he pummels the man who attempts to rape Fanny (Fielding, 1979, pp. 142-43). And this is after failing to snatch a gun from a cowardly ex-soldier who flees from involvement in this fight (Fielding, 1979, p. 141). The inn-keeper who annoys him for suggesting cutting off Joseph's leg receives the full force of Adams' anger, for which Adams gets splashed all over with pig's blood from this in-keeper's wife (Fielding, 1979, p. 126). Trulliber survives narrowly when he readies to attack him but sees the clenched "club fist" and that crab stick (his walking stick), a wellknown deadly weapon. Another squire well known as "the great hunter of men" (Fielding, 1979, p. 227) and especially a "parson hunter" sadistically sets his hounds at Adams for sport: Adams now turns another hare to hunt, and his cassock takes the full wrath of the tearing curs. Adams employs his famous crab stick and together with Joseph, he pounds many to death before the squire desperately calls away the survivors.

So, whereas many critics find him a man of two worlds: an ascetic too committed to his faith and religion, and a man who shares with all of us the joys and strife dictated by circumstances (Shaver, 1941; Mace, 2018; Brennan, 2010; Watt, 1960; Sumpter, 1978), it still baffles why he then fails to read the world and people more intelligently. This fighting force in him looks 'animal-like', such as of an instinctive reaction when a beast is provoked. He seems never to bother about even the most basic of decencies: dress and cleanliness. Fielding knew the symbolic significance of a cassock (priestly humility, authority and decency), but he lets his hero go in a torn, dirty symbol, which really turns selfridicule. No wonder at the squire's he is seen as dirty, foolish and shameless, "a villain" and a "cur" leading "thieves". 
We could add to this list of idiosyncrasies many others, but, let us add only one more behavior of Adams that has puzzled many critics: his escapade at night, naked, at the estate of the Boobies' country home. Fielding sets up a risible scene of grotesque naked bodies at night (Prior, 1997) in which, ironically, the impotent Didapper seeks out Fanny's room for sex and ends up in Slipslop's room, only to meet this aroused sex maniac; he attempts to escape, but she is determinedly after him, pulling him to herself as she pretends to shout for help. Aroused and alarmed thinking it is Fanny under attack, Adams runs out naked only to meet a fleeing Didapper and then, suddenly lands into Slipslop's "mountains of breasts". She grabs him and he must wrestle himself free amid her shouting for help. Lady Booby is approaching in the corridor with candlelight, and he manages to slip away from Slipslop, turning the wrong way where he escapes into Fanny's room and quietly slides under the bedding near her body. He knows he is with Fanny. Then we read,

Adams lay by the side of Fanny, ignorant of the paradise to which he was so near, nor could the emanation of sweets which flowed from her breath, overpower the fumes of tobacco which played in the parson's nostrils. And now sleep had not overtaken the good man, when Joseph, who secretly appointed Fanny to come to her at the break of day, rapped softly at the chamberdoor, which when he had repeated twice, Adams cry'd, Come in, whoever you are. Joseph thought he had mistaken the door, tho' she had given him the most exact directions; however, knowing his friend's voice, he opened it, and saw some female vestments lying on a chair. Fanny waking at the same instant, and stretching out her hand on Adams' beard, she cry'd out, - 'O Heavens! Where am I?' 'Bless me! Where am I?' said the pastor. Then Fanny screamed. Adams leapt out of bed, and Joseph stood, as the tragedians call it, like the statue of Surprise. "How came she into my room?' cry'd Adams. 'How came you into hers?' cry'd Joseph in an astonishment. 'I know nothing of the matter,' answered Adams, 'but that she is vestal for me. As I am a Christian, I know not whether she is a man or woman. He is an infidel who doth not believe in witchcraft. They sure as exist now as in the days of Saul. My clothes are bewitched away too, and Fanny's brought into their place... (Fielding, 1979, pp. 313-314)

Fielding hastens to tell us Joseph's strong belief in Adams' faithfulness could not allow him to suspect Adams of any wrongdoing at all. However, this is what we have noticed already about Fielding's narration trick: always in the background to convince "good-natured" people (characters and readers) (Mace, 2018, p. 16) to believe without questioning. According to Prior (1997), this is a scene that has caused most controversy among critics. For Prior, many have seen it as a symbolic representation of continued casting of Adams' 'child innocence' and a night symbol of the dark hearts of the Slipslops (because even in the scene, Slipslop's carnal heat is dangerously aroused once more); other critics have found it outright farce for entertainment, and, therefore, a continued ridiculing of an ironic hero. But, Prior wants to convince us that the scene may show Adams as an object of comic laughter for his nakedness in a farcical, extravagant piece (Prior, 1997, p. 108), but it offers more. Prior offers us the following interpretations: it offers a climax to Slipslop's carnality and a futile self de-emasculation of Didapper (p. 111); it also maintains a consistent extravagant behavior of Adams because, throughout the novel, his stature has been an image of a powerful giant: the ox-like knuckle of his fist, his incredible 
nimbleness and speed no horse or coach can overtake him; his manipulation of any stubborn horse; his extraordinary appetite at the wedding feast of the Joseph, so that

There is something of the Pantagruelian in Adams' physical appearance and conduct. (For) he possesses an unmannerly energy greater and more dramatically diffuse than that of either Didapper or Slipslop... their grotesquerie is largely a risible incarnation of their narrow moral limits. Adams' grotesquerie has its roots in his benign deficiencies... his absent-mindedness, his naiveté, his harmless hypocrisy. But through the representation of this diffused grotesquerie, this ultimately delightful Pantagruelian physical excess, Fielding indulges in a ridicule that is unfocused, almost completely free of satiric venom... His actions are exaggerated as they are elsewhere in the novel... . He concludes that he has been bewitched... (Prior, 1997, pp 111-112)

Well, it all sounds as if Fielding must be allowed to keep a religious monstrosity, a marvel, too large for life and too complex for us to understand really fully. A living Fielding would have been the best riddlesolution - to tell us if he had one and only one meaning for this scene. But it is interesting that Prior harps also on Adams' belief in witchcraft. If witchcraft was part of eighteenth-century belief (by all Christians), then we accept it, but if it is some belief to extend into the twenty-first century, more problems arise about this Christian hero. But, couldn't this irreligious twist be part of his inability to define very clearly to himself what kind of Faith his soul holds? For instance, at the end of the novel when he learns his most beloved son has drowned and died (misinformation), his mind races through many puzzling un-Christian sentiments: to Adams now, Abraham was a fool to accept the temptation to sacrifice his beloved son; he tells Joseph (and all of us) to be wary of loving our wives too much - it must be in moderation. Yet, on the journey, he destroys Aeschylus for joy, listening to the lovers swearing undying love for each other.

\subsubsection{Adams' Protégée, Joseph Andrews}

He is also drawn as a symbol of chaste and humble living as expected of every Christian, a hero of and a lesson in chastity. But, according to Maurer (2005), with his limited home-education and earning a 'hand to mouth' kind of life, parentless and with no known company, his too much humility, incorruptibility and gentility become questionable. This comes out glaringly when we consider the tough masculinity, he is endowed with even at the age of seventeen (Fielding, 1979, p. 42). Then Fielding almost turns him into a female hero with an effeminate description: Lady Booby sees him as 'the handsomest and genteelest footman in the kingdom" (Fielding, 1979, p. 47), no wonder every woman wants to court him, instead of vice-versa. This, of course, is a grotesque outcome from idealizing his virtues too much. Even before Fanny, he is always the humbler, a near subservience to a future wife. The too much intelligence and wisdom he is given do not anchor him into this world. After all, he is illiterate. For instance, before the solicitous Mrs. Slipslop and even Lady Booby, he is quietly resisting, browbeaten into silent rejection; we hardly see in him a man giving punching verbal rebuttals. This grotesqueness again is because women seem to emasculate him. Battestin (1959) explains this humility and soft nature (a good-natured tool) of Joseph as Fielding's plotting to use the character to display chastity by affiliating him to the Biblical Joseph. He adds that Joseph Andrews becomes Fielding's 
proposition of the usefulness of the goodness in a man to be used as an example to imitate. This is how he, too, turns an idealized symbol of purity and virtue, and is given Fanny who is equally a flat, idealized symbol (Battestin, 1959, pp. 29-28).

Maurer (2005) refuses to credit Joseph with being a good example of male chastity for its own sake because the narrator relates Joseph's abstinence to what any good partner should be - keeping a strong attachment to a partner. Mauer states, “Joseph's example, therefore, is less of the chaste male per se than of the man who experiences and enacts sexual desire only within the context of a monogamous attachment leading to marriage” (Maurer 2005, p. 107). Maurer gives more reasons to support the exaggerated and idealized chastity in a man by refusing to believe a Joseph-Lady Booby sexual relationship would be tantamount to adultery because Fielding makes a mistake of removing/killing Sir Booby thereby freeing the widow from marital obligations (p. 107). What the reader gets displayed, therefore, is a passive virtue merely harnessed to episodes of refusal to have sex, not even with Fanny till the day of marriage. In fact, Fielding seems to have wished readers to remember all the traditional religious conditions that make an ideal Sacrament of matrimony, abstinence being one of the key prerequisites. Joseph's passiveness in the novel is actually very loud; apart from his participation in the fight against a squire's hounds, there is no other action of note, except of course his "meditation-like" resistance against sex. But, connected to this is another important message Fielding is making: the Josephs and Wilsons of society should remind readers of the importance of eschewing the many broken marriages and cohabitation cases Wilson details to Adams (us).

Yet, as many critics have pointed out again, these weaknesses in characterization do not influence the trend of the story because the novelist has shaped his events and settings to prejudice the reader to note more the intention: themes. For instance, in a fighting scene or where Adams clobbers the would-be rapist of Fanny, Fielding asks us not to blame Adams but to see the evils of his attacker and sympathize with the man of God and the future husband of this angelic girl. So, as Battestin (1959, p. 43) puts it, the whole novel form is intentionally designed to place Joseph along Adams for this symbolic pilgrimage (an analogy of Abrahams' sojourn from Egypt to Canaan) through a savage-vain world. The "virtuous footman and a benevolent parson serve as a constant commentary upon the pretentious and inhabitable". This is what brings out another fault in the novel: moralizing, which is discussed below.

\subsubsection{Wilson}

Fielding keeps on harping on "good-natured" people whom he endows with charity, benevolence and love of mankind, exactly in the vein of his style of Biblical allusion to the Good Samaritan. Such people are meant to be loved by the reader because, even those who have been bad, all their faults have been excused (Mace, 2018). Wilson is among these. He is the best example of how Fielding's garrulous omniscience style can indeed blind a reader from realizing the cruel irony in the subtext of the novel. Wilson is presented as a repentant sufferer: he has gone through chaotic, debauched living in London amid prostitutes, wayward and directionless youth. There is no better master of a life of fleshpots than he is, and we cannot forget that particularly horrid betrayal of a de-virgined woman he abandons to 
destitution, prostitution and eventually to prison. What tells the reader Fielding wants Wilson seen as the best example of a man of charity are Adams' groans and sighs of mild disapproval, but full of admiration at the return of a prodigal to the flock of the Lord. Adams (Fielding) is even particularly more impressed by the responsible and popular man Wilson has become: a most exemplary married life, rich from the loving wife's inheritance, adding more riches to this with his sweat, and has proved he will not look condescendingly on low ones and the needy. And Adams has been won over to this 'saint' even more for the financial help and excellent hospitality Wilson gives. So far Fielding's thematic objective is achieved - the reader has appreciated what it means to love others as you love yourself, to have active charity. We cannot deny Wilson's roundness of character. Nevertheless, as we are to see later in, all this is an authorial design (Sumpter, 1978, p. 20), and critics have found Wilson another of those impositions, never involved in action, but is a mere tool of Fielding's commentary on his ideology, just like it would be in a summon in a church, trusting the "good-natured reader" or listener to accept Wilson's benevolence (Mace, 2018).

\subsubsection{Women Characters}

Because the second key theme of the novel is affectation (and its vices of hypocrisy and vanity), women characters are again passed through well-contrived episodes to display these vices. Undoubtedly, Mrs. Slipslop, Lady Booby and Betty are "painted parodies of the romantic excess" as found in eighteenth-century novels (Brennan, 2010, p. 66), and highly comical figures stereotyping the typical amatory excesses of the women of fashion even by the low-bred women. We do not blame Joseph for acting robot-like when confronted by Lady Booby and Mrs. Slipslop, one after another, for almost a fortnight, and the two even suddenly finding out they know they are chasing the same man. It is a masterpiece of high comedy, almost like sequencing scenes in a play, with the audience in raucous laughter because all lady decorum has gone and there is a cutthroat competition of old women almost going to fists over a very handsome, shy, young man, passively standing there to be wooed, won. Mrs. Slipslop's malapropism and pseudo-intellectualism add to the comedy, just as much as Lady Booby's drooling and groaning solicitations do.

Again, the intention of Fielding is to exalt male chastity, an indirect answer "to the exaltation of feminine virtue" Richardson had wanted to advance in Pamela (Shaver, 1941, p. 85). The triumphs of Joseph over the string of women authorial stage-managing is doing is certainly a demonstration of "the value and sacredness of sensual abstention, consistently (which) exemplifies the significant axiom that strength of mind, under all tempting situations, is the producing and the sustaining source of ultimate and enduring happiness" (Shaver, 194, p. 85). This is ultimately where all the women gossip and idle talk about Leonora is leading (Mace, 2018) — neither Horatio nor Bellarmine, the man of fashion, can match the tenacious hold on chastity exhibited by Joseph. But Fielding is slowly collecting humanity and grouping them into thematic categories. For instance, Mrs Graveairs, leader of the gossips, and ironically the grave snob, will not travel in the stage-coach with the commoners like Joseph. Mrs. Slipslop will not travel with such snobs who boast of high-class origin but have never known even what it implies to have servants! (Fielding, 1979, p. 109). Yet, commoner Joseph is a sexual target of high- 
class Lady Booby and low-class Slipslop. And so, Fielding collects all these women gossips and the wooers of Joseph together to inform the reader, in an apostrophe,

Be it known, then, that the human species are divided into two sorts of people... high people and low people... High people signify no other than people of fashion and the low people those of no fashion. ((And the high fashion lot have selfishly seized) courts, assemblies, operas, balls, et c. (And those of no fashion relegated to) hops, fairs, revels, et c (to complete the segregation). It is sufficient that so far from looking on each other as brethren in the Christian language, they seem scarce to regard each other as of the same species. Thus, the terms strange persons, people one does not know, the creature, wretches, beasts, brutes...". Unfortunately, even people like Mrs. Slipslop have imitated their betters in calling those of their rank similar animal appellations. (Fielding, 1979, pp. 158-59)

In these battles for sex, there is not any class war going on. Fielding is thematically connecting all women, low or high, under one vice: affectation and its twin vices - vanity and hypocrisy. By stringing together these episodes, Fielding convinces the reader to see these women as symbols of those vices Fanny has shunned. Their vulgarity and total lack of decorum are throughout the story contrasted to Fanny's humility and virgin innocence. This is why the description of Fanny is all the time of a reserved girl, extremely protective of her virginity. This description is heightened by the simple but bright colors on her wedding day. Rejecting fancy dressing suggested by Pamela, she prefers her fine 'white thread stockings..., (her) little straw hut lined with cherry-colored silk, and tied with a cherry-colored ribbon...; (and her deportment one of) the extraordinary and unaffected modesty of Fanny" (Fielding, 1979, p. 321). What Joseph encounters in his bridal bed is a gift adorned not by ostentatious jewels of showy women but the charms of gifted nature (Fielding, 1979, p. 322). And, typical of a sermonizing narrator, Fielding, in a flowery, poetic and celebratory tone invites us to marvel at the celebration of virginity from two paragons of his theme,

How, reader, shall I give thee an adequate idea of this lovely young creature! The bloom of roses and lilies might a little illustrate her complexion, or their smell her sweetness: but to comprehend her entirely, conceive youth, health, bloom, beauty, neatness, and innocence in her bridal bed; conceive all these in their utmost perfection, and you may place the charming Fanny's picture before your eyes. (And together, prepared) to enjoy the perfect rewards of their constancy: rewards so great and sweet that I apprehend Joseph neither envied the noblest duke, nor Fanny the finest duchess that night. (Fielding, 1979, p. 322)

It is not surprising, therefore, that this scene suddenly gets contrasted to how Lady Booby ends in debauchery, back in the vices of London: into the arms of a young captain of dragoons, together with eternal parties at cards (Fielding, 1979, p. 323).

\subsubsection{The Surgeon, the Judge and Magistrates and Squires}

Bartkuviene (2017, p. 26) helps us to appreciate Fielding's use of the highway, a journey as a key style: the "setting in a comic epic is a countryside, its local roads and highways, woods and inns, 
and houses of different people" all combine to indeed turn Joseph Andrews into an epic. The wars and clashes of a heroic epic become those fights, beatings and rude rejections travelers have to withstand in inns, at roadsides, in woods, in the stage-coach, in squires' courtrooms, etc. All these converging points on this journey serve to indicate the inevitable mixing of people irrespective of class or gender, for, when they meet at an inn or in a coach or in a courtroom, what they discuss or quarrel about is what matters to Fielding (Webster, 2018, p. 101). We have seen this earlier when Mrs. Graveairs and other women begin an altercation, affectation is tested, the hypocrites and the vain are discovered. Similarly, Fielding has placed the so-called leaders of the people along the highway in the same settlements as the poor because this is his way of leading us to see how this affectation and the vanity-hypocrisy relationship is played out not only by those in high circles but by even the Slipslops and Graveairs who have become copycats of the so-called aristocratic respectability. At the same time, these places in the setting are not merely social gatherings but also "commercial centres": money is exchanging hands willingly and even forcibly through thefts, bribes, extortion, etc. Human predators are waiting, waylaying victims for profit-making (Webster, 2018, p. 106). The religious and secular powers represented along this highway, therefore, are satirized as we observe them accosting Fielding's travelers, arresting them for petty reasons, refusing them charity but solicitous of payments for any little service they may render. The highway is now a trap-zone for self-aggrandizement of corrupt leaders and for the cutthroat commercial traders, the Tow-wouses. No wonder criminals have also found this highway a good trapping zone. The highway is society. Fielding is saying corruption in society has reached very worrying levels where man is preying on man; it is the symbolic hunt of any squire, of any corrupt Pastor, of any trapper taking up the symbol of the ever-ready hunting hounds.

So, Fielding wants the reader to view these leaders as false agents of authority grouped under corrupt power and the tyranny of authority (Sumpter, 1978; Webster, 2028; Shaver, 1941). This is why they come practically into every scene where the pilgrims are confronted with attacks, fighting or accusations. It is also significant that squires in this satire double as magistrates, wearing legal authority they are incapable of interpreting properly because this is hampered by selfish motives, personal profit (Sumpter, 1975, p. 38). Moreover, of course, the arrogance (affectation) these leaders display is owing to the power of ill-gotten wealth. For instance, facing a squire in court, as Adams has proved, is like facing God's judgment, eternal damnation on earth. The "parson-hunter" Adams has to meet, for example (Fielding, 1979, pp. 199ff) is a sadist who wants Adams to feel the weight of a magistrate's power: he will not attend to Adams till he has had his supper, and drunk more liquor to get drunker; poking jokes at a terrified Fanny is meant to show her the unlimited harm he is capable of inflicting on her. Men who have lost a sense of responsibility and decency can hardly appreciate the immense anguish they cause to the poor, the defenseless.

The worst injustice, however, is the glaring display of mistreatment of the low and the poor. Those with power and aristocratic privileges do not only oppress but also prey and parasite. Like in the case of Adams, you can escape torture and injustice if you bear the label "gentleman" or a man of "high class". Scott is exploiting this privileged position of a law-man to execute the wishes/demands of Lady Booby because of the power she wields in the parish. Fielding's irony is hitting hard at social position 
and wealth, given the powerful mandate to deprive the poor of peace, safe living. Apparently, the vices of London are now creeping into the countryside; Fielding's journey motif has succeeded in exposing the complex nature of corruption in the nation. These leaders, therefore, are an advanced form of those robbers ganging to steal sheep, rob and beat up travelers. A squire can even rape with impunity. The nation is in chaos.

\subsubsection{The Narrator Weaknesses in the Style of Novel Execution}

These weaknesses, according to many critics, come from Fielding's choice of what he termed a comic epic in prose that had never been attempted before. Watt (1957) in particular does not find much 'originality' in this so-called new epic mode because Fielding is still tied up to the composition rules of epic: "Joseph Andrews has five out of the six parts under which Aristotle considered epic; but then it is surely impossible to conceive of any narrative whatever which does not in some way contain "fable, action, characters, sentiments, and diction'..." (Watt, 1957, p. 248). He adds,

Were it not for the Preface we would surely be justified in taking Joseph Andrews as a parody of epic procedures rather than as the work of a writer who planned to use them as a basis for the new genre: and even if we take account of the Preface, Fielding's novel surely reflects the ambiguous attitude of his age, an age whose characteristic literary emphasis on the mock-heroic reveals how far it was from the epic world it so much admired. (Watt, 1957, p. 253)

So, Fielding's so-called new distinctions are actually a recasting of what Aristotle and very many previous writers had been dealing with. And to many critics, Watt (1957), Steward Bock (1990), Kettle (1960), Battenstin (1959), et al, it is this misconception of having 'founded' a new mode of writing that got him carried away with the experimentation of fusing many elements of story-telling, character, action et c. Watt (1957), Stewart Bock (1990), Radloff (1957), Battanstein (1959), Kettle, et al. (1960) agree with Brennan's (2010) summary of this experimentation,

Fielding chose not to write a first person, subjective narrative in which the author remains silently in the background as an editor, unlike many of his peers who did this in an attempt to "disclaim the fictional nature of their work under the guise of documents and history" (Brown: 27). Instead, he chose to create an external, dramatized narrator who is intrusive, self-reflexive, and authoritative, a figure who plays an undeniably important and prominent role in the text. The voices and ideas (in the novel) are all filtered through the consciousness of this dramatized narrator who identifies himself not just as the teller of a tale but also as the author of the novel. (Brennan, 2010, p. 57)

And, to many critics, this is what again brings up the various stylistic clashes whereby a reader has to sort out the key narrator from a host of voices: a commentator, a preacher, a digressing voice, a dramatic aside man, etc. The narrator, therefore, ensures control of themes, tone, events and characters, exerting his authority to ensure readers see the story through his own comic and ironic viewpoint (Brennan, 1957). This viewpoint begins to expose some of the faults. We examine the effects of this below. 


\subsubsection{Moralizing, Preaching and Confusing Voices}

This style takes many forms: asides, direct commentary and apostrophizing. This starts right from the Preface where he labors to explain to the reader his theory of epic prose and what he wants it for: to depict the evil consequences of the deadly affectation - vanity and hypocrisy, by not focusing on anyone known person but by examining the experiences he has gone through, witnessed (JA, pp. 28-30). The Preface, therefore, lays down the theme of the story, which the reader is to follow throughout. This, therefore, gives Fielding a chance to go on reminding the reader about it. For instance, in Book 1.1, he right away explains how he is going to plot the theme. In Book 1.7, he ends the chapter with an apostrophe that sounds a prayer, beginning — "O Love, what monstrous tricks dost thou play with thy votaries of both sexes ..." (Fielding, 1979, p. 55). Another long aside and moralizing follows in Bk 1. 8 (Fielding, 1979, pp. 58-59), following Lady Booby's fiasco at wooing Joseph. At the end of the following chapter, Bk 1.9 (Fielding, 1979, pp. 62-63), he inserts another aside commenting on the follies of sexual wooing by women in high circles. And so on and so forth... So that, Watt's argument (1959) about this style that "Fielding's garrulity about his characters and his conduct of the action" summarizes the irritations of many critics and readers,

As far as most modern readers are concerned it is not Fielding's moral but his literary point of view which is open to objection. For his conception of his role is that of a guide who, not content with taking us 'behind the scenes of this great theatre of nature', feels that he must explain everything which is to be found there; and such authorial intrusion, of course, tends to diminish the authenticity of his narrative. (And this approach) is quite consistent with Fielding's major intention - it promotes a distancing effect which prevents us from being so fully immersed in the lives of the characters that we lose our alertness to the larger implications of their actions implications which Fielding brings out in his capacity of omniscient chorus. (Watt, 1959, pp. 284-85)

Therefore, as noted above, characters lose the authority to be themselves to influence us to appraise them appropriately outside being Fielding's vehicles of themes and ideas. This "bullying role in shaping and controlling readers' perceptions" (Brennan, p. 58) produces double irony: he turns his actors flat and the unconscious irony with which the chief mouthpiece, Pastor Adams, speaks and acts makes him no more credible in a reader's mind because he makes his heroes (mouthpieces) all the more flawed, manufactured... (Shaver, 1941; Mace, 2018; Brennan, 2010; Sumpter, 1978). Kettle (1960) adds to this accusation,

Clearly a novelist who permits himself - in his role of commentator - such as asides is weighting the scales against himself as an artist... There is no reason whatever why such asides should not be made in a novel, but to be accepted by the reader, they must always be appreciable within the total experience of the novel as a work of art. (Kettle, 19960, p. 36)

And with Joseph Andrews they are not appreciable because another complication emerges. 


\subsubsection{Confusing Voices:}

Readers' apparent confusion is worsened by the polyphonic nature of the novel (Brennan, 2010, pp. 56-57): it is peopled with many voices including the embedded letters and made more complex by the writer's own insistent commenting (Steward Bock, 1990, p.200). Therefore, Fielding must find a way to control all these voices using the subjective narration "in which the author remains silently in the background as an editor", controlling how the reader is to respond to each voice, to the author's ideology. For instance, in Books 2 and 3, the novelist steps forward to do what is done in sermons. He wants to justify, give credence to his writing. He forces his strong views and dogma down our throats. He hammers out his intentions/themes to bias readers to take his side, which is not always palatable to discerning readers. A preachy satire weakens itself precisely because the writer has diluted its power to use irony, humor and detachment to let them dictate the hidden intention. This is precise because satire should allow readers to find other hidden views and then sieve out what to take or reject.

Mace (2018) puts this in a form of accusation: Fielding causes readers to fail to understand well the characters because "our ability to discern character is often undermined by the narrator, who actively misleads the reader in making false judgments about character (so) we are placed in a position where we are required to judge character based on misleading, inaccurate information". Mace dwells at length on Wilson as an example of a character whose image and vices Fielding controls (2018, pp. 4-7) refusing readers to appraise the character in totality. In the previous sections, we briefly reviewed Wilson's ugly past, a criminal record we do not just brush away, even if we forgive him. Then towards the end of the novel, we are baffled by the apparent loss of faith Adams exhibits in the face of a calamity to the family, a trial actually like God's request of Abraham to sacrifice his son: Adams' most beloved son is drowned and dead (misinformation because a benevolent passing Pedlar stumbles on the accident and saves the boy). But Adams is ignorant of this, and he succumbs to despair (Fielding, 1979, p. 291), alluding to Abrahams' apparent heartlessness in accepting to lose a beloved child. Yet, Adams has been seriously advising Joseph not to despair (when there is a possibility of Fanny being his sister). He has even derided Joseph's remark that a mistress so much loved by him (Joseph), if there were one, would pain him a great deal if she died. Adam calls this foolishness, wrong in itself from the implication of "mistress". But, immediately after this reprimand, he advises Joseph to love his Fanny/wife "in moderation", to which Mrs. Adams roundly castigates him: his type of love/doctrine is irreligious, selfish, and poisonous (JA, p. 292). And the wife remarks "I am certain you do not preach as you practice; for you have been a loving and a cherishing husband to me”. Earlier Joseph (Fielding) had remarked to him, rather sarcastically, that it is easier to give advice than take it (Fielding, 1979, p. 291). So, soon, when he exhibits the sudden despair at a son's "loss", Mace (2018) calls this hypocrisy, a stand irreconcilable with the strong, ascetic believer that has dominated the narrative.

\subsubsection{Plotless, Fragmented Story}

This has been blamed on lack of a good plot and the nature of the story: it is an episodic and picaresque adventure where accidental meetings and other unforeseeable happenings occur, things you cannot plan for. Yet, a plot is thought an essential tool to signpost causality in a work of art so that the reader can explain why things occur the way they do. But, as Kettle (1960) once more asserts, 
No one could maintain that Joseph Andrews has too much plot. Indeed, in so far as plot has the function of holding together the subject-matter in an organized way, it has too little. It is held together, not by a story but by certain themes and also, in a subtle way, by its basic form, that of a journey. The journey of Joseph and Adams from London to Lady Booby's country seat has a certain symbolic quality about it: it is a journey not simply of adventure but of discovery. (It is) a symbol of man's life and striving is, of course, common in literature... . (Kettle, 1960, p. 72)

And, as readers follow this journey, they have the impression this is the plot. But the problem comes with explaining how, for example, the stories of Leonora and Wilson come into the plot. So, like many critics, Kettle (1960) maintains, the novel has a weak plot; we only discern bits of it from the way Fielding stands "larger, more insistent than any of his creations, directing our attention, controlling our reactions, imposing the pattern" (Kettle, 1960, p. 73). This is best done using the theme of Christian, common charity (unselfish, actively practiced) which is constantly following characters Fielding exposes to the reader because he has intentionally made it the key litmus test of all characters we are made to meet and examine. We have to constantly find out if we agree with the views of Mrs. Touwouse: "Common charity a f_t!" says she; "common charity teaches us to provide for ourselves, and our families; and I and mine won't be ruin'd by your charity, I assure you" (Fielding, 1979, p. 72). So, the reader, by being shifted from scene to scene, listening to and examining each character or group of characters, almost automatically forced to make conclusions where he should belong. We even seem not to notice that coincidences are smuggled into the story when, for instance, Fanny suddenly falls on the scene as if, on very short notice, she must report nursing her sick Joseph. We do not even question how Joseph happens not to have parents for twenty years plus, leave alone how Pamela comes to be a sister, till we come to the end of the novel when, suddenly, Andrew and Wilson have been smuggled into the story to fix the jig-saw puzzle.

So, we could say that each chapter of Joseph Andrews is self-contained, almost independent of the rest, enjoyable without what happened before or is to happen after. Those little summaries at the end of each chapter seem to lend credence to this because, it is as if the author has finished 'a book' and rounds it off with a reminder of what you have been dealing with. Also, this is because of the nature of publishing at the time - serializing and later binding into a book, with, perhaps some little editing here and there.

We have detailed these weak elements of Fielding's novel to emphasize how Fielding, on the other hand, deals with too many characters and too complicated 'plot' to give the single individual virtue or vice sufficient, convincing dramatization. Besides this tendency of his 'plot', it is also part of Fielding's intention as a moralist to put every phenomenon into its larger perspective. Sexual virtue and sexual vice, for example, are placed in a broad moral perspective, and the results do not always produce the kind of emphasis that the sexual reformer would wish (Watt, 1957, p. 288).

\subsection{Continued Relevance of Joseph Andrews}

When critics say this novel digressed from being a parody to turning a critical commentary on many evils of eighteenth-century England, they are spot on as seen in (Watt, 1959; Kettle, 1960; Mace, 
2018; Shiver, 1941; Sumpter,1975). As reviewed above in the treatment of the setting, Fielding goes much further than treating only affectation and the related vices-hypocrisy and vanity. For instance, the novel treats these three evils in a philosophical twist whereby, because of affectation and hypocrisy among leaders, corruption and animalism have escalated to unacceptable levels since they have entered the very institutions which should be protecting the sanctity of law and religion. At this level, readers no more get too preoccupied with whether Adams or Joseph can be believable human beings but whether, in using them, Fielding was able to drive home the ridiculed carriers of vices. This is the point Battestin (1959) is making. He argues that any looseness in the plot, such as the episode involving Wilson, leads us to focus on the classical ideal that Fielding intended to sell to the English society, namely, morality, ethical traditions, a return to God (Battestin, 1959, pp. 52-53). And, indeed as Battestin repeats, very many authors of the eighteenth century onwards harped on the same theme as society evils escalated. And this continues today (Battestin, 1959, p. 46). In fact, Shaver (1941) recommends seeing Fielding's greater role in the shaping of the novel by focusing attention on the symbolic significance of setting in Joseph Andrews as a style that thrusts the novel into a universal appeal. He believes Richardson set his linear Pamela in a "hot-house" whereas Fielding set Joseph Andrews (though also linear) in every part of the nation, any nation (Shaver, 1941, pp. 160-161). Fielding may not have gone all the way to discuss class differences, but the setting still strongly implies the theme especially when we consider the role of Wilson, the Leonora-Bellarmine episodes and the Boobies' characterization in the narrative. JosephFanny coupling is not merely for a display of chastity, but it stretches its philosophical, metaphysical significance into underscoring a crucial socioeconomic point: that riches are not the only source of good marriages and decent living.

Shaver (1941) has also found contemporary relevance of this novel in the controversial perennial question of justice and political decency. The moment men find corruption the only means of becoming money magnets and society paragons instead of using equity, decency and industry, then morals and brotherhood begin to fall apart. Lady Booby's corruption of Law is a good example of what modern society has witnessed: the powerful in government making and influencing laws to favor the rich and why "the rich never break laws". Fielding says he meant to display no real men and women in his work, but, a discerning reader sees millions of them around us symbolized in those characters within the setting. Every episode opens to us characteristics of men and women we recognize, we live and share life with; the quack doctors, the materialistic pastors; the sadistic magistrates, etc. This is how the power of satire works: allowing us to stretch our imagination to see beyond the letters, to reach "the real, actual true-to-life-experiences... (For) though crude in nature, his narrated episodes are vivid pages from the book of contemporary English life" (and any nation's) (Shaver, 1941, p. 78). Human beings all over the world are part of this stage-coach in the novel; it is a symbol; it is all over the novel because even individual homes become a stage-coach. So, we are exposed anywhere we live. Shaver (1941) again summarizes the point thus,

Fielding, without prejudice or sensationalism, calmly presents a sweeping picture of contemporary life (for he) believes that society is a great masquerade: and if one would see persons and events as they actually are, he must first of all strip men of their vanity. (Then) the 
real innate characteristics frequently overshadow the superficiality of vain pretences... (So he) represents the observations and the convictions of people who have seen the social world in its ugliest phases... (Shaver, 1991, p. 89)

\section{3- Conclusion}

This study has detailed the importance of Joseph Andrews as a very important landmark at the beginning of the modern novel. The study has examined its strengths and weaknesses, given the significant changes that have taken place in novel writing since the time of writing Joseph Andrews. The study has also examined its relevance today given the mirror it holds before us to examine our modern shortcomings as characters and as part of corrupt institutions we serve. It is, therefore, a compelling piece of literature that has rightly outlived its time. Variously called an 'experimental novel' by many critics in the past, we think this label has left the 'belittling' impression it used to carry, given the position it holds in our modern Literature Departments and its thematic relevance to modern times. In our modern way of appraising intertextuality, we find many modern texts returning over and over to the evils Joseph Andrews points out: political corruption among civil servants, bribery and extortion, lechery and prostitution, vanity and materialism, hypocrisy from the clergy and the laity in equal measure, etc. Just as Pastor Adams feels Aeschylus be part of his personality, we feel Fielding's work form part of every literary scholar's companion, too.

\section{References}

[1] Allen, W. (1963). The English novel. Penguin Books.

[2] Backscheider, P. R. (2005). Why Fanny can't read: Joseph Andrews and the (ir)relevance of literacy. In P. Backscheider \& C. Ingrassia (Eds.), A Companion to the Eighteenth-Century English Novel and Culture. 167-190 Blackwell Publishing Ltd.

[3] Baker, A. E. (1957). The History of the English novel: Vol. II. The Elizabethan age and after. Barnes and Noble.

[4] Bartkuvienè, L. (2017). English literary history of the eighteenth century. Viliniaus Univeriteto Leidykla.

[5] Battestin, Martin. (1959). The moral basis of Fielding's art: A study of Joseph Andrews. Wesleyan.

[6] Bock, S. (1990). Aspects of style in the novels of Henry Fielding. [Unpublished doctoral dissertation]. University of Cape Town.

[7] Brennan, B. (2010). Henry Fielding's epistolary voices: Polyphony and the embedded letter in Joseph Andrews, Tom Jones and Amelia. [Unpublished doctoral dissertation]. The Catholic University of America.

[8] Downie, J. (1997). The making of the English novel. Eighteenth Century Fiction, 9(3), 249-266. 
[9] Fallon, R. J. (1988). Henry Fielding and the language of morals: An experiment in contextual reading. [Unpublished doctoral dissertation]. University of Leicester.

[10] Fielding, H. (1979). Joseph Andrews. Penguin.

[10] Hailes, P. R. (1969). Moral basis in Fielding 's irony. [Unpublished master's thesis]. University of Richmond URS.

[11] Kettle, A. (1960). An introduction to the English novel (Vol. 2). Harper Torchbooks.

[12] Mace, R. K. (2018). Character on trial: Reading and judgment in Henry Fielding's works. [Unpublished doctoral dissertation]. Plymouth University (UK).

[13] Maurer, L. S. (2014). From Egypt To Eden: Archetypal narratives and idealized virtue in Henry Fielding's Joseph Andrews. Interfaces 35, 105-124.

[14] Prior, T. J. (1997). Classical and grotesque bodies: Some aspects of courtesy literature and the mid-eighteenth-century comic novel. [Unpublished doctoral dissertation]. University of Toronto.

[15] Radloff, T. (1957). Fielding's theory and art of composition. [Unpublished master's thesis]. Loyola University.

[16] Robertson, Scott. (2008). Henry Fielding: Literary and theological misplacement. [Unpublished doctoral dissertation]. University of Glasgow.

[17] Shaver, J. R. (1941). A Comparative study of Samuel Richardson and Henry Fielding. [Unpublished master's thesis]. North Texas State College.

[18] Sneddon, S. (1998). A Reassessment of the early fiction of Henry Fielding. Toronto University.

[19] Sumpter, E. (1975). Authority figures in Henry Fielding's Joseph Andrews, Tom Jones and Amelia. The University of British Columbia.

[20] Taylor, W. L. (1934). The contribution of the eighteenth-century periodical to the development of the novel in England. [Unpublished master's thesis]. Texas University.

[21] Watt, Ian. (1957). The rise of the novel: Studies in Defoe, Richardson and Fielding. University of California Press.

[22] Webster, M. (2018). Essential and ubiquitous: The inns of eighteenth-century British fiction. Houston University. 